\title{
PENGARUH PENDAPATAN PERKAPITA, PDRB, DAN JUMLAH PENDUDUK TERHADAP TINGKAT KONSUMSI MASYARAKAT KABUPATEN ACEH TAMIANG TAHUN 2003-2016
}

\author{
Hijri Juliansyah ${ }^{\mathrm{a} 1}$, Nurbayan ${ }^{\mathrm{a} 2}$ \\ ${ }^{a}$ Fakultas Ekonomi dan Bisnis Universitas Malikussaleh \\ 1Corresponding author: hijri.juliansyah@gmail.com \\ 2 nurbayan9sp@gmail.com
}

\section{A R T I C L E I NF O RMA T I O N}

A B S T R A C T

Keywords:

Income per capit, the GDP, Population and Consumption
The Purpose of this study is to see the influenceof per capita income, GRDP and Population to the consumption of the Aceh Tamiang people. The data uses in this research is from 2003-2016. The multiple linear regression uses to analyze the influence of independents variables to dependent variable. The result show that per capita income, GRDP and population influence.

\section{1.}

\section{PENDAHULUAN}

Konsumsi merupakan pembelanjaan yang dilakukan oleh rumah tangga dan jasa, konsumsi memiliki peranan penting dalam kehidupan masyarakat,konsumsi ialah kebutuhan pokok yang harus di penuhi setiap masyarakat baik kebutuhan pokok maupun kebutuhan non makanan, konsumsi juga di pengaruhi dari tingkat pendapatan dan penghasilan seseorang, semakin naiknya pendapatan seseorang maka semakin naik juga tingkat konsumsinya. Diberbagai negara pengeluaran konsumsi sekitar 50-75\% dari Produk Domestik Bruto (PDB) hingga konsumsi rumah tangga mempunyai dampak dalam menentukan fluktuasi kegiatan ekonomi dari satu waktu ke waktu lainnya disebabakan konsumsi masingmasing berbanding lurus dengan pendapatannya. Berikut adalah data pendapatan perkapita, PDRB, jumlah penduduk dan konsumsi di kabupaten Aceh Tamiang dalam beberapa tahun kebelakang.

\section{Tabel 1}

Data Pendapatan Perkapita, PDRB dan Jumlah Penduduk Kabupaten Aceh Tamiang 20112013

\begin{tabular}{|c|c|c|c|c|}
\hline Tahun & $\begin{array}{c}\text { Pendapatan } \\
\text { Per Kapita } \\
\text { (Rupiah) }\end{array}$ & $\begin{array}{c}\text { PDRB } \\
\text { (Rupiah) }\end{array}$ & $\begin{array}{c}\text { Jumlah } \\
\text { Penduduk } \\
\text { (Jiwa) }\end{array}$ & $\begin{array}{c}\text { Konsumsi } \\
\text { (Rupiah) }\end{array}$ \\
\hline 2011 & 9.109 .035 .05 & 120.518 .947 & 257.681 & 941.129 \\
\hline
\end{tabular}

\begin{tabular}{|l|l|l|l|l|}
\hline 2012 & 17.408 .264 .63 & 127.459 .336 & 130.853 & 994.196 \\
\hline 2013 & 18.868 .854 .50 & 42.024 .086 & 269.007 & 853.115 \\
\hline
\end{tabular}

Sumber :Badan Pusat Statistik Kabupaten Aceh Tamiang, 2017

Dari tabel 1 di atas menunjukakan setiap masyarakat memiliki tingkat konsumsi yang berbeda, Aceh Tamiang termasuk kabupaten yang dapat di bilang tinggi tingkat konsumsi masyarakatnya, seperti kita lihat pada tahun 2011 pendapatan pendapatan perkapita masyarakat Aceh Tamiang sebesar Rp.9.109.035.05 dengan tingkat konsumsi masyarakatnya Rp. 941.129 semakin tinggi pendapatan maka tingkat konsumsinya pun meningkat. Pada tahun 2011 PDRB masyarakat Aceh Tamiang sebesar Rp. 120.518.947 dengan tingkat konsumsinya lebih besar Rp. 941.129, karena pada tahun 2011 PDRBnya Kabupaten Aceh Tamiang mengalami penurunan. Tetapi pada tahun 2011 jumlah penduduk masyarakat Aceh Tamiang 257.681 jiwa dengan tingkat konsumsi yang lebih tinggi sebesar Rp. 941.129.

Oleh sebab itu pada tahun 2011 tingakat konsumsi masyarakat Aceh Tamiang lebih besar di bandingkangkan dengan pendapatan perkapita, PDRB dan jumlah penduduk juga sama. Kerena tingkat konsumsi masyarakat Kabupaten Aceh Tamiang meningkat disebabkan pendapatan yang 
tinggi maka tingkat konsumsi juga mengalami peningkatan.

Kemudian pada tahun 2012 pendapatan perkapita Aceh Tamiang mengalami peningkatan sebesar Rp.17.408.264.63 dengan tingkat konsumsinya mengalami kenaikan hingga Rp. 994.196 Sedangkan PDRB masyarakat Aceh Taming pada tahun 2012 Rp. 127.459.336lebih tinggi dibandingkan dengan tingkat konsumsi masyarakat Rp. 994.196 Pada tahun 2012 jumlah penduduk Aceh Taming 130.853 jiwa lebih rendah di bandingkan dengan tingkat konsumsinya Rp. 994.196.

Jadi pada tahun 2012 tingkat konsumsi mengalami penurunan dibandingkan dengan pendapatan perkapita,PDRB dan jumlah penduduknya. Alasannya karena pada tahun 2012 pendapatan perkapita meningkat tetapi jumlah penduduk mengalami penurunan jika jumlah penduduk sedikit maka konsumsi masyarakatnya juga sedikit.

Pada tahun 2013 pendapatan perkapita Aceh Tamiang sebesar Rp. 18.868.854.50, dengan tingkat konsumsinya yang menurun Rp. 853.115 yang menurun, Sedangkan PDRB Aceh Tamiang pada tahun 2013 juga mengalami penurunan hingga Rp. 42.024.086. Akan tetapi lebih besar dengan tingkat konsumsinya meningkat Rp. 853.115.Akan tetapi pada tahun 2013 jumlah penduduk mengalami penurunan hingga 269.007 jiwa tetapi tingkat konsumsi yang meningkat Rp. 853.115 pada tahun 2013.

Penyebab pendapatan perkapita mengalami peningkatan adalah pada tahun 2013 keadaan ekonomi yang baik, tetapi konsumsi mengalami penurunan. Sedangkan PDRB tahun 2013 juga mengalami penurunan di sebabkan rendahnya daya beli masyarakat tetapi konsumsi juga mengalami penurunan juga, akan tetapi pada tahun 2013 jumlah penduduk mengalami penurunan akan tetapi konsumsinya mengalami kenaikan.

Berdasarkan uraian diatas maka dapat diambil perumusan masalahnya adalah seberapa besar pendapatan perkapita, PDRB dan jumlah penduduk terhadap tingkat konsumsi masyarakat kabupaten Aceh Tamiang 2003-2016. Dari uraian tersebut dirasa perlu diadakan penelitian lebih lanjut terkait dengan tingkat konsumsi Aceh
Tamiang. Adapun tujuan penelitian ini adalah untuk mengetahui serta menganalisis pengaruh pendapatan perkapita, PDRB dan jumlah penduduk terhadap tingkat konsumsi masyarakat kabupaten Aceh Tamiang 2003-2016.

\section{TINJAUAN TEORITIS \\ Pengertian Konsumsi}

(Nababan, 2013)mengatakan bahwa: Konsumsi secara keseluruhan adalah sebagai pemakain semua jenis barang-barang dan jasa yang secara langsung akan memenuhi kebutuhan manusia. Konsumsi sebagai pembelian yang dilakukan oleh rumah tangga atas barang-barang dan jasa dengan tujuan untuk memenuhi kebutuhan dari orang yang melakukan pekerjaan tersebut. Teori konsumsi Keynes di dasarkan atas hukum psykologis yang mendasar tentang konsumsi. Muana menjelaskan : apabila pendapatan naik, maka konsumsi juga akan naik juga. Pengeluaran konsumsiadalah kata lain fungsi dari pendapatan disposibel.

\section{Fungsi Konsumsi}

Keynes membuat dugaan-dugaan mengenai fungsi konsumsi berdasarkan instrospeksi dan observasi kasual. Dugaan tersebut diantaranya adalah kecenderungan mengkonsumsi marjinal, kecenderungan mengkonsumsi rata-rata dan konsumsi tersebut dipengaruhi oleh pendapatan serta tidak memiliki hubungan yang penting dengan tingkat bunga. Kecenderungan mengkonsumsi marjinal (Marginal Propensity to Consume / MPC) maksudnya adalah jumlah yang dikonsumsi apabila adanya tambahan pendapatan yang memiliki nilai antara nol hingga satu.

\section{Pengertian Pendapatan Perkapita}

(Tristanto, Arisman, \& Fajriana, 2013). Pendapatan perkapita adalah besarnya semua pendapatan dan semua jumlah penduduk di suatu wilayah negara negara.Pendapatan per kapita didapatkan dari hasil pembagian pendapatan nasionalsuatu negara denganjumlah penduduk negara pada suatu periode tertentu. Pendapatan per kapita dapat dipakai untuk melihata tingkat kesejahteraan atau standar hidup suatu negara dari tahun ke tahun. Denganmelakukan bandingan 
seperti itu, kita dapat mengamati apakah kesejahteraan masyarakat padasuatu negara secara rata-rata telah meningkat. Pendapatan perkapita yang meningkat merupakan salahsatu tanda bahwa rata-rata kesejahteraan penduduk telah meningkat. Pendapatan perkapita memperlihatkan pula apakah kemajuan pembangunan yang telah dilaksanakan oleh pemerintah telah berhasil,berapa besar keberhasilan tersebut, dan akibat apa yang timbul oleh peningkatan tersebut.

\section{Pengaruh Pendapatan PerKapita Terhadap konsumsi}

Pendapatan perkapita adalah besarnya pendapatan rata-rata penduduk di suatu negara.Pendapatan per kapita didapatkan dari hasil pembagian pendapatan nasionalsuatu negara denganjumlah penduduk negara pada suatu periode tertentu. Pendapatan perkapita dapat digunakan untuk membandingkan kesejahteraan atau standar hidup suatu negara dari tahun ke tahun.Pendapatan perkapita merupakan faktor yang sangar penting untuk suatu negara jika pendekatan perkapita naik maka konsumsi masyarakat juga meningkat dan kesejahteraan masyarakat juga meningkat.

\section{Pengertian Produk Regional Bruto (PDRB)}

(Syahrullah Dio, 2012). Semua barang dan jenis jasa sebagai hasil dari hasil kegiatankegiatan perekonomian yang aktifsuatu diwilayah domestik tanpa memperhatikan apakah faktor produksinya berasal atau dimiliki oleh penduduk daerah tersebut, ialah jenis produk domestik yang bersangkutan pendapatan yang timbul oleh karena adanya kegiatan produksi tersebut merupakan pendapatan domestik. Yang di maksud dengan wilayah domestik suatu daerah adalah meliputi daratan dan lautan yang berada dalam garis geografis daerah tersebut. Wilayah administrasi suatu pemerintah dengan tingkat I,tingkat II, dan desa merupakan wilayah domestik propinsi, kabupaten/kota, dan desa.

\section{Pengertian Jumlah Penduduk}

(Persaulian et al., 2013). Jumlah penduduk adalah semua orang yang sah yang tinggal suatu daerahatau Negara serta menuruti semua aturandan ketentuan-ketentuan dari daerah atau Negara tersebut. BesarnyaPendapatan Asli Daerah dapat dipengaruhi oleh jumlah penduduk, jika jumlah penduduk Meningkat maka pendapatan yang ditarik juga akan meningkat (Nurul Badriyah, 2001).Penduduk merupakan sumber daya utama yang berpengaruh besar terhadap pembangunan di suatu wilayah. Menurut, Population Reference Bureau (Nurhayati \& Rahman, 2003).Jumlah penduduk memegang peranan penting dalam pembangunan ekonomi.Penduduk merupakan sejumlah manusia yang menempati suatu daerah tertentu pada waktu tertentu. Jumlah penduduk biasanya dikaitkan dengan pertumbuhan (incomeper capita) negara tersebut, yang secara kasar mencerminkan kemajuan perekonomian negara tersebut.

\section{METODE PENELITIAN}

Penelitian ini dilakukan di Kabupaten Aceh Tamiang, yang menjadi objek penelitian ini adalah pendapatan perkapita,PDRB dan jumlah pendduk terhadap tingkat konsumsi masyarakat diKabupaten Aceh Tamiang.Penelitian ini menggunakan metode Analisis regresi log-linear berganda adalah menjadi model yang memuat lebih dari satu variabel penjelas kecenderungan satu variabel-variabel dipenden pada satu lebih variabel lain,variabel yang menjelaskan. (M. firdaus, 218, 2014).Analisis log-linear menjelaskan dengan menggunakan pengolahan data EVIEW 9.

Adapun persamaannya adalah sebagaai berikut : $\mathrm{LnY}=\mathrm{B} 0+\mathrm{Bi} \operatorname{Ln} \mathrm{x} 1+\mathrm{B} 2 \operatorname{Ln} \mathrm{x} 2+\mathrm{B} 3 \mathrm{Ln} \mathrm{x} 3+\mathrm{ei}$

\section{Keterangan :}

\begin{tabular}{|c|c|}
\hline Y & $=$ Tingkat Konsumsi \\
\hline B0 & $=$ Konstanta \\
\hline B1 B2 B3 & $=$ Koefesien Regresi Variabel \\
\hline Ln $x 1$ & $=$ Pendapatan Perkapita \\
\hline $\operatorname{Ln} \times 2$ & $=\mathrm{PDRB}$ \\
\hline $\mathrm{n} \times 3$ & $=$ Jumlah Penduduk \\
\hline & $=$ Error Term( Variable Penganggu) \\
\hline
\end{tabular}




\section{HASIL PENELITIAN DAN \\ PEMBAHASAN}

\section{Uji Asumsi Klasik}

a. Uji Normalitas

Uji normalitas bertujuan untuk menguji apakah dalam model regresi,variabel penganggu atau residual mempunyai distribusi normal atau mendekati normal. Model regresi yang yang baik adalah memiliki distribusi data yang normal atau mendekati normal.
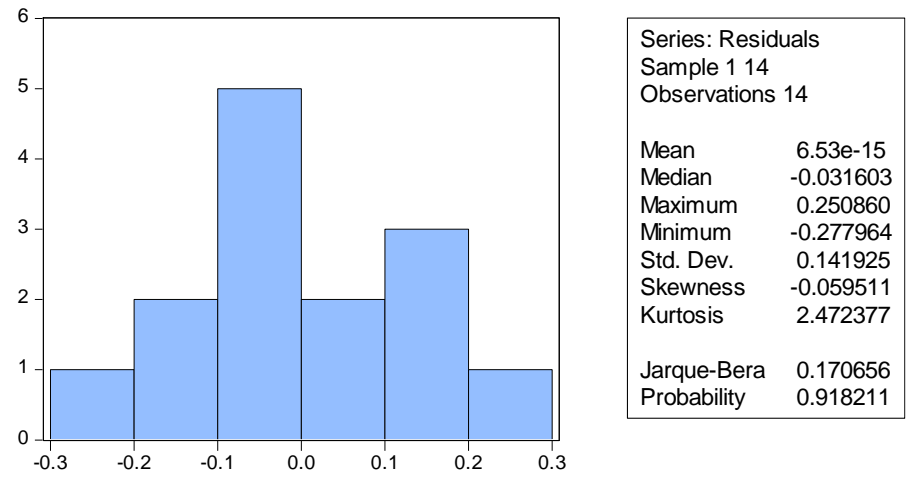

\section{Gambar 1 \\ Uji Normalitas}

Nilai Prob. JB hitung sebesar 0,918211>0,05 maka residual model ini terdistribusi dengan normal.

\section{b. Uji Autokorelsi}

Uji autokorelasi bertujuan untuk melihat apakah dalam model regresi liniear ada korelasi antara kesalahan pengganggu pada periode 1 dengan kesalahan pengganggu pada periode $\mathrm{t}$ 1(sebelumnya).

\section{Tabel 2}

\section{Hasil Uji Lagrange Multiplier}

Breusch-Godfrey Serial Correlation LM

Test:

\begin{tabular}{lccc}
$\begin{array}{l}\text { F-statistic } \\
\text { Obs*R- } \\
\text { squared }\end{array}$ & 0.039251 & $\begin{array}{c}\text { Prob. F(2,8) } \\
\text { Prob. Chi- } \\
\text { Square(2) }\end{array}$ & 0.9617 \\
\hline \hline
\end{tabular}

Sumber : Hasil Penelitian 2018 ( Data diolah)

Berdasarkan tabel 2 di peroleh nilai probabilitas Chi-Square $\left(X^{2}\right) 0.9342$ lebih besar dari nilai kritis $(\alpha=5 \%$ atau 0,05$)$, sehingga maka kesimpulannya model terbebas dari gangguan outokorelasi.

\section{c. Uji Heteroskedastisitas}

Uji Heteroskedastisitas bertujuan untuk menguji apakah dalam model regresi terjadi keditaksamaan varian dari residual suatu pengamatan yang lain.cara untuk mendeteksi heteroskedastisitas dapat dilakukan dengan menggunakan uji white antara nilai prediksi variabel terikat (dependen).

Tabel 3

\section{Hasil Uji Heteroskedastisitas}

Heteroskedasticity Test: White

\begin{tabular}{lccc}
$\begin{array}{l}\text { F-statistic } \\
\text { Obs*R- }\end{array}$ & 2.187158 & $\begin{array}{c}\text { Prob. F(6,7) } \\
\text { Prob. Chi- }\end{array}$ & 0.1646 \\
$\begin{array}{l}\text { squared } \\
\text { Scaled }\end{array}$ & 9.129938 & Square(6) & 0.1664 \\
$\begin{array}{l}\text { explained } \\
\text { SS }\end{array}$ & 3.429263 & $\begin{array}{c}\text { Prob. Chi- } \\
\text { Square(6) }\end{array}$ & 0.7534 \\
\hline
\end{tabular}

Sumber: Data Diolah (2018)

Berdasarkan tabel 3 di atas menunjukkan dapat dilihat bahwa nilai Prob (P-value) Obs*Rsquare adalah $0.1664>0,05$ maka dapat di simpulkan bahwa tidak terkena, heteroskedastisitas.

\section{d. Uji Multikolonearitas}

Multikololinearitas (kolinearitas ganda) pertama kali di temukan oleh ragner frisch, yang berarti adanya hubungan linear yang sempurna atau yang pasti di antara yang beberapa atau semua variabel penjelas bebas (Nilai VIF). dari model regresi ganda.

\section{Tabel 4}

\section{Hasil Uji Multikolonearitas}

Variance Inflation Factors

Date: 02/24/18 Time: 19:50

Sample: 114

Included observations: 14 Coefficie Uncenter nt ed Centered

\begin{tabular}{cccc} 
Variable & Variance & VIF & VIF \\
\hline C & 88.2235847168 .40 & NA \\
LOG $(X 1)$ & 0.0056513573 .603 & 1.339832 \\
LOG $(X 2)$ & 0.0171569401 .586 & 1.648893
\end{tabular}




\section{Sumber: Data diolah (2018)}

Berdasrkan tabel 4 di atas dapat di lihat bahwa nilai VIF yaitu 1.339832 maka dapat di simpulkan nilai VIF lebih kecil dari 10 yang berarti di dalam penelitian ini tidak menunjukan adanya multikolonearitas.

\section{e. Uji R2}

Untuk mengetahui pengaruh pendapatan perkapita, PDRB dan jumlah penduduk terhadap konsumsi dapat di lihat dariR ${ }^{2}$. Dari hasil pengujian di peroleh hasil nilai $\mathrm{R}^{2}$. Adalah sebesar 0.5464 yang berarti bahwa besarnya pengaruh pendapatan perkapita, PDRB dan jumlah penduduk terhadap tingkat konsumsi adalah sebesar $0.5464(54,64 \%)$ sedangkan yang di pengaruhi oleh variabel lain di luar model ini adalah adalah sebesar 0,45,36 (45,36\%). Hubungan dari koefisien korelasi R adalah R- akar $\mathrm{R}^{2}=$ akar $0.5464=0,739188744=0,7392$.

\section{f. Pembuktian secara persial ( uji t)}

Uji $\mathrm{t}$ dilakukan untuk melihat signifikan dari pengaruh variabel bebas secara individual terhadap variabel terikat dengan mengangap variabel bebas lainnya adalah konstan (Gujarati, 2011). Berdasarkan padaTabel 4.5 hasil analisis linear berganda menunjukkan bahwa variabel pendapatan perkapita sebesar 3,820193 dengan probnya 0,0034 dan niali t-tabel dengan nilai $\mathrm{df}$ $=\mathrm{n}-\mathrm{k}=14-4=10$ pada alpa $0,05 \%$ maka di peroleh nilai sebesar 1,81246 maka di simpulkan bahwa thitung> t-tabel yaitu sebesar 3,820193 > dari 1,81246 yang berarti bahwa Ha2 diterima dan Ho2 di tolak. Yang berarti secara persial pendapatan perkapita berpengaruh terhadap tingkat konsumsi ini bisa juga di lihat dari probabilitas statistik $0,0034<0,05$ berpengaruh secara positif dan signifikan terhadap variabel konsumsi. Sedangkan variabel PDRB 2,843630 dengan probabilitasnya 0,0174 dan nilai $\mathrm{t}$-tabel dengan nilai $\mathrm{df}=\mathrm{n}-\mathrm{k}=14$ $4=10$ pada alpa 0,05 maka di peroleh nilai sebesar 1,81246 maka di simpulkan bahwa t-hitung >ttabel yaitu sebesar 2,843630 > dari 1,81246 yang berarti Ha3 terima dan tolak Ho3 ditolak. Yang berarti secara persial PDRB berpengaruh terhadap tingkat konsumsi hal ini dapat di lihat probabilitas statistik $0,0174>$ dari alpa 0,05 berpengaruh secara positif dan signifikan terhadap variabel tingkat konsumsi.Variabel jumlah penduduk sebesar $-0,224830$ dengan probabilitasnya 0,8266 dan nilai t-tabel dengan nilai $\mathrm{df}=\mathrm{n}-\mathrm{k}=14-4=10$ pada alpa $0,10 \%$ maka dapat diperoleh nilai 1,81246 maka disimpulakan bahwa t-hitung -> ttabel yaitu sebesar $-0,224830<$ dari1,1.377218 yang berarti bahwa $\mathrm{H} 04$ terima $\mathrm{Ha} 4$ di tolak berarti tidak berpengaruh dan tidak signifikan.(Gujarati, 2011).

\section{g. Pembuktian secara simultan (uji f)}

Uji f dilakukan untuk mengetahui apakah setiap variabel variabel independen secara keseluruhan signifikan secara statistik dalam mempegaruhi variabel dependen. Apabila nilai $\mathrm{f}$ hitung lebih besar dari f tabel maka variabelvariabel independen secara keseluruhan berpengaruh secara terhadap variabel dependen hipotesis yang di gunakan (Gujarati, 2012). Dari pengujian tabel 4.5 menunjukkan bahwa variabel pendapatan perkapita,PDRB dan jumlah penduduk terhdap variabel tingkat konsumsi memiliki fhitung sebesar 6,221880 dengan prob-statistik sebesar 0,011772 dan nilai f-tabel dengan df (k-1) $(\mathrm{n}-\mathrm{k})=(4-2)(14-4)=(3)(10)$ pada alpa 0,05 di peroleh nilai sebesar 3.71 maka dapat disimpulkan bahwa f-hitung > f-tabel yaitu sebesar 6,221880 > 3,71 Ha1 diterima Ho1 ditolak yang berarti Secara bersama-sama variabel pendapatan perkapita, PDRB dan jumlah penduduk berpengaruh secara signifikan dan positif secara dan signifikan terhadap variabel tingkat konsumsi hal ini juga bisa dilihat dari probabilitas hitung yaitu sebesar $0,011772<0,05$

\section{Pembahasan}

\section{a. Pengaruh Pendapatan Perkapita Terhadap Tingkat Konsumsi Masyarakat}

Berdasrkan tabel di atas t-hitung . t-tabel atau 3,820193 > 1,81246 dqn nilai prob. T-hitung dari variabel pendapatan perkapita sebesar 0,0034 yang lebih kecil 0,05 sehingga hipotesis Ha dan tolak Ho artinya variabel pendapatan perkapita berpengaruh secara signifikan dan positif terhadap 
tingkat konsumsi masyarakat. Adanya pengaruh positif menunjukan apabila tinggi pendapatan perkapitanya maka konsumsinya juga meningkat.

\section{b. Pengaruh PDRB Terhadap Tingkat Konsumsi Masyarakat}

Berdasarkan tabel di atas t-hitung. t-tabel atau 2,843630>1,81246 degan nilai prob. T-hitung dari variabel PDRB sebesar 0,0174yang lebih kecil 0,05 sehingga hipotesis $\mathrm{Ha}$ dan tolak Ho artinya variabel pendapatan perkapita berpengaruh secara signifikan dan positif terhadap tingkat konsumsi masyarakat. Adanya pengaruh positif menunjukan apabila tinggi PDRB maka konsumsinya juga meningkat.

\section{c. Pengaruh Jumlah Penduduk Terhadap Tingkat Konsumsi Masyarakat}

Berdasarkan tabel di atas t-hitung . t-tabel atau $-0,224830<1,81246$ degan nilai prob. Thitung dari variabel jumlah penduduk sebesar 0,8266 yang lebih kecil 0,05 sehingga hipotesis terima $\mathrm{Ha}$ dan tolak Ho artinya variabel jumlah penduduk berpengaruh secara signifikan dan positif terhadap tingkat konsumsi masyarakat. Adanya pengaruh positif menunjukan apabila tinggi PDRB maka konsumsinya juga meningkat.

\section{KESIMPULAN DAN SARAN}

\section{Kesimpulan}

Berdasarkan hasil penelitian pengaruh pendapatan perkapita, PDRB dan jumlah penduduk terhadap tingkat konsumsi masyarakat Kabupaten Aceh Tamiang yang telah di bahas serta perhitungan statistik untuk menguji hipotesis yang telah dilakukan analisis log linear berganda maka penulis menarik kesimpulan sebagai berikut

1. Variabel-variabel bebas yaitu pendapatan perkapita,PDRB dan jumlah penduduk secara bersama-sama (simultan) dalam jangka pendek dan jangka panjang mempunyai pengaruh yang signifikan dan positif terhadap variabel terikat tingkat konsumsi.

2. Secara persial dalam jangka pendek dan jangka panjang variabel pendapatan perkapita berpengaruh secara positif dan signifikan terhadap tingkat konsumsi masyarakat Aceh Tamiang

3. Besarnya pengaruh variabel pendapatan perkapita, PDRB dan jumlah penduduk Kabupaten Aceh Tamiang terhadap tingkat konsumsi sebesar 0,546495 dan sisanya mengambarkan pengaruh variabel lain di lain di luar penelitian ini.

\section{Saran}

Dengan adanya penelitian ini diharapka pemerintah Aceh Tamiang :

1. Dapat membantu masyarakat dalam peningkatan konsumsi rumah tangga/masyarakat dalam

2. Dapat membantu untuk meningkatan pendapatan masyarakat dengan cara, menciptakan dan membuka lapangan pekerjaan bagi penduduk setempat), agar lebih baik kedepannya seiring dengan kenaikan penduduk setiap tahunnya di Kecamatan Aceh Tamiang

3. Perlunya sosialisasi dan peran pemerintah dalam pemerataan penduduk daerah.

\section{DAFTAR PUSTAKA}

Anggraini, N. (2012). Hubungan Kausalitas Dari Tingkat Pendidikan, Pendapatan, Dan Konsumsi Terhadap Jumlah Penduduk Miskin Di Provinsi Jawa Tengah. Jurnal Ekonomi.

Badan Pusat Statistik . (2010). Aceh Tamiang Dalam Angka. Badan Pusat Statistik Aceh Tamiiang

. (2003). Aceh Tamiang

Dalam Angka. Badan Pusat Statistik Aceh Tamiang

Dalam Angka. Badan Pusat Statistik Aceh Tamiang

(2005). Aceh Tamiang

Dalam Angka. Badan Pusat Statistik Aceh Tamiang

Dalam Angka. Badan Pusat Statistik Aceh Tamiang

. (2007). Aceh Tamiang

Dalam Angka. Badan Pusat Statistik Aceh Tamiang 
Dalam

Anggraini, N. (2012). Hubungan Kausalitas Dari

Tingkat Pendidikan, Pendapatan, Dan

Konsumsi Terhadap Jumlah Penduduk

Miskin Di Provinsi Jawa Tengah. Jurnal Ekonomi.

Badan Pusat Statistik . (2010). Aceh Tamiang Dalam Angka. Badan Pusat Statistik Aceh Tamiiang

Dalam Angka. Badan Pusat Statistik Aceh Tamiang

Dalam Angka. Badan Pusat Statistik Aceh Tamiang

(2005). Aceh Tamiang

Dalam Angka. Badan Pusat Statistik Aceh Tamiang

(2006). Aceh Tamiang

Dalam Angka. Badan Pusat Statistik Aceh

Tamiang

Dalam Angka. Badan Pusat Statistik Aceh Tamiang

Dalam Angka. Badan Pusat Statistik Aceh Tamiang

Dalam Angka. Badan Pusat Statistik Aceh Tamiang

Dalam Angka. Badan Pusat Statistik Aceh Tamiang

(2011). Aceh Tamiang

Dalam Angka. Badan Pusat Statistik Aceh

Tamiang.

Dalam Angka. Badan Pusat Statistik Aceh Tamiang

Dalam Angka. Badan Pusat Statistik Aceh Tamiang

Dalam Angka. Badan Pusat Statistik Aceh Tamiang (2015). Aceh Tamiang

Dalam Angka. Badan Pusat Statistik Aceh Tamiang

(2016).Aceh Tamiang

Dalam Angka. Badan Pusat Statistik Aceh

Tamiang

Dian Ariani. (2014). Analisis Faktor-Faktor

Yang Mempengaruhi KonsumsI. Jurnal
Ekonomi Dan Kebijakan Publik Indonesia, 1, $1-7$.

Firdaus, M. (2011). Ekonometrika Suatu Pendekatan Aplikatif.Edisi Kedua Jakrta Aksara.

Giang, R. R. (2013).Pengaruh Pendapatan Buruh Bangunan Universitas Sam Ratulangi.Issn 2303-1174 .Jurnal Emba, 1(3), 248-256.

Gujarati, D. (2012). Dasar-Dasar Ekonometrika, Selamba Empat. jakarta selatan.

Hakim Muttaqim, B.SOc.Sc., M.Ec, D. (2014). Analisis Pengaruh Pendapatan Keluarga Terhadap Konsumsi Rumah Tangga Dikecamatan Banda Sakti. FE Almuslim.

Hotmaria Sitanggang. (2014). Analisis FaktorFaktor Yang Mempengaruhi Konsumsi Masyarakat Disumatera Utara. Jurnal Tabularasa Pps Unimed Vol.11 No.2, Agustus 2014j. Jurnal Tabularasa Pps Unimed Vol.11 No.2, 11(2).

Murohman. (2011). Pengeluaran Konsumsi Rumahtangga Di Indonesia.

Nababan, septia s. . (2013). Pendapatan Dan Jumlah Tanggungan Pengaruhnya Terhadap Pola Konsumsi Pns Dan Dosen Dan Tenaga Kependidikan Pada Fakultas Ekonomi Dan Bisnis Universitas Sam RatulangI. ISSN 2303-1174, 1(4), 21302141.

Nurhayati, Siti Fatimah, \& Rahman, M. (2003). Analisis Faktor-Faktor Yang Mempengaruhi Fungsi Konsumsi Masyarakat Di Provinsi Jawa Tengah Pada Tahun 2000.

Persaulian, B., Aimon, H., \& Anis, A. (2013). Analisis Konsumsi Masyarakat. Jurnal Kajian Ekonomi, I(2), 1-23.

Sadono, S. (2011). Ekonomi Makro, edisi ketiga, bina grafika jakarta.

. (2012) Ekonomi Pembangunan. PT. buku seru. Syahrullah Dio. (2012). Analisis Pengaruh

Produk Domestik Regional Bruto (PDRB) Pendidikan, Dan Pengangguran Terhadap Kemiskinan Di Provinsi Banten Tahun 2009-20112. Jurnal Emba.

Tristanto, Arisman, A., \& Fajriana, I. (2013). Pengaruh Jumlah Industri, PDRB Dab Pendapatan Perkapita Penerimaan Pajak Reklame Sebagai Pendapatan Asli Daerah Kota PalembangJurnal Ekonomi, (X).

Yudas pasoba. (2014).Pengaruh Perkembangan Penduduk Dan PDRB Terhadap Konsumsi Masyarakat Dimalaguone Kabupaten Talaud. 